\title{
ANIMALS, TALE TYPES, AND BELIEF NARRATIVES IN ARGENTINEAN FOLKLORE
}

\author{
María Inés Palleiro \\ Buenos Aires University \\ National Scientific and Technical Research Council (CONICET) \\ Argentina \\ Email: marinespalleiro@gmail.com
}

\begin{abstract}
Tales regarding transformations of animals, expressing social beliefs related to the relationship between humans, animals, and supernatural beings, are spread all over the world. This paper deals with the intertwining of ritual discourse, animal tales, and other folk narrative genres, all of which express the differential identities of local groups. The aim is to discuss the relevance of belief narratives in an Argentinean catalogue of tale types, whose first volume includes animal tales. Following the models of Monika Kropej Telban (2015) and Camiño Noia Campos (2010), who include in their indexes of Slovenian and Galician folktales textual examples of each tale type, my purpose is to show the local transformation of universal tale types in the catalogue of Argentinean folktales. I analyze textual examples of this blend between tale types and belief narratives with the aim of proposing a classification of Argentinean folktales not only into tale types but also into narrative matrices, which share thematic, structural, and stylistic features. The goal of this folk narrative catalogue is to show how local beliefs transform universal narrative patterns into expressions of vernacular identities.

To contextualize this approach concentrating on the interweaving of animal tales and belief narratives, I also present a diachronic overview of Argentinean folk narrative collections focused on animal tales, from 1921 up to the present day.
\end{abstract}

Keywords: animal tales, Argentina, belief narratives, folklore genres, tale types

\section{INTRODUCTION AND THEORETICAL STARTING POINTS}

When considering the social restraint in the definition of folklore, Abrahams (1971: 16) characterizes, as a point of departure, folklore as a sum of all traditional expressions and implementations of knowledge operating within a community, comprising an embodiment of social beliefs. In this sense, he stresses that knowledge, to be transmitted, must be embodied; whereas institutions or value structures are abstracts of culture, folklore is an aggregate of concretions. 
When dealing specifically with folklore genres, he takes into consideration the content and structure of performances, in a complex interweaving of simple forms. Folk narratives, as verbal expressions of social identities, may be either highly codified items, such as folktales and fairy tales, or simply codified ones, such as legends and anecdotes. Many animal tales show a mixture of these genres in a polyphonic message, in which fictional creatures cross the boundaries of belief discourse. In fact, in Argentinean folktales, in which fairies do not exist, there is an interweaving between animal tales, marvelous tales, and belief narrative genres such as legends. Linda Dégh (2001) stresses that all legends are based on beliefs, to the extent that she considers the term "belief legend" as a pleonasm. All these narrative genres are closely related to daily experiences and beliefs in the societies in which they circulate (Blécourt 2012), and serve as reaffirmations of commonly held values of the group to whose tradition they belong (Tangherlini 1990).

All these considerations reveal the ways folk narrative patterns change constantly while responding to the exigencies of different societies. From this standpoint, I focus attention on those narratives that explore the boundaries of historic experience with the cognitive modality of belief, considered as a modal expression in which the true value of discourse depends on social consensus (Greimas \& Courtès 1982; Palleiro 2008a). According to my classificatory goal, such interweaving between different narrative genres that can be observed in concrete performances should be included in a catalogue of folktales.

\section{RHETORIC OF BELIEVING AND THE QUEST OF TRUTH}

As it is well known, Aristotle characterizes rhetoric as the art of persuasion, whose counterpart is dialectics, based on logic syllogism, also pointing out that the aim of rhetoric is not to reason but to convince and appeal to beliefs (Butcher 1902). Rhetoric deals also with anomalies (Ducrot \& Todorov 1983) that refer to the rupture of an epistemic paradigm. From this starting point, I focus the attention of this paper on the narrative construction of beliefs whose true value depends not on reasoning but on a collective agreement.

When speaking about beliefs, it is worth considering the argumentative use of metaphors, both as figures of language and as cognitive issues. From this perspective, metaphors constitute anomalous expressions which serve as resources of persuasion not only in literary speech but also in daily life (Lakoff \& Johnson 1987). Belief narratives can be considered as discursive manifestations of such anomalies which go beyond the borders of epistemic knowledge, towards the ontological arenas of belief. Narrative, as a cognitive principle, which organizes 
experience in a sequential order (Bruner 2003), provides structural patterns to articulate social beliefs in discursive formats.

The dimension of truth leads to the problem of believability (Palleiro 2008a; Astapova 2015). Since the true statement of belief depends on a social or interpersonal agreement, in belief narratives there is always a quest for such believability, supported by argumentative strategies to make the discourse accepted. In this way, belief narratives are based on modal affirmations oriented to convince the addressee about the credibility of the message. Another important aspect which factors into believability is the relationship between fiction and reality. It is worth considering Todorov's distinction between the categories of "marvelous", "uncanny", and "fantastic" tales (Todorov 1981 [1980]). ${ }^{1}$ While marvelous tales belong to the dominion of fiction, and uncanny ones remain within the limits of real experience, fantastic ones, instead, belong to a vanishing zone in which there is a gap between reality and fiction. When dealing with supernatural beliefs, Hufford (1995) considers such vanishing narratives as rooted in real experiences, representing discursive attempts to explain out of ordinary facts. Likewise, other belief genres such as myths are experienced as real (Siikala 2002). White (1973) focuses attention on the poetics of history, dealing with fictional elaboration of reality, in a dynamic tension with the illusion of reality of fiction (Barthes et al. 1970; Barthes 1971). Such dynamics can be identified in Argentinean living folktales which show the interweaving between fiction and reality in folk narrative, opening the boundaries of folklore genres such as Märchen towards fantastic tales and legendary discourse. A catalogue of Argentinean folktales, then, should include such living examples of folk narratives, in which fiction and reality are mixed up in the flexible arenas of belief.

\section{DETAILS, MATRICES, AND HYPERTEXTUAL ITINERARIES IN FOLK NARRATIVE}

From a formalist perspective, Jan Mukařovský (1977) describes the structure of folk art as a "mosaic-like" heterogeneous addition of semantic units, also underlining the semantic relevance of apparently irrelevant changing details as the basic semantic issue in folk art. In the constructive process of folktales, such details act as mnemonic tracks, which activate totally or fragmentarily thematic, compositional, and stylistic features, whose combination constitutes a folk narrative matrix. This concept of "narrative matrix" adds to the thematic regularities classified into tale types, structural and rhetoric issues identified by intertextual comparison of different narrative versions (Palleiro 2004, 2018). ${ }^{2}$ Thus characterized, each matrix constitutes a pre-textual pattern stored in 
the memory of folk narrators. Such pre-textual patterns, comprising thematic, compositional and stylistic features stabilized along the diachronic process of oral (and written) tradition, are transformed with the addition, suppression, substitution, or displacement of these changing details, generating alternative itineraries in different communicative situations. In this way, each narrative matrix acts as a germinal nucleus of versions and variants displayed in different contexts (Palleiro 2004, 2018). The folktale's genesis is thus based on the transformation of narrative matrices in new cultural environments, expressing the differential identity of each social group (Palleiro 2018). However, the concept of narrative matrix is a classifying issue, deployed with the aim of cataloging folktales in an archive. Following Derrida (1997), I deem the archive in its etymological sense of arkhé - or cognitive organization principle - as well as in the sense of a material and symbolic space for storing memory.

Thus characterized, the matrix turns out to be similar to the disseminative structure of a virtual hypertext, whose flexible links favor the generation of alternative routes. ${ }^{3}$ From this starting point, the structure of animal tales and other subgenres of Märchen can be compared to that of hypertext, characterized by Nelson (1992) as a flexible combination of textual blocks, freely set by the user of a virtual system. The dispersive itineraries of the folktale, in their different versions and variants, reflect the flexile linkages of memory (Assman 1997 [1992]; Palleiro 2004, 2018). My proposal of classifying folk narratives into matrices emphasizes the transformation of thematic topics, structural patterns, and rhetoric strategies as a result of the influence of social beliefs bound to vernacular contexts (Palleiro 2004, 2008a, 2018).

\section{ANIMAL TALES IN ARGENTINEAN FOLK NARRATIVE COLLECTIONS: CHANGING DETAILS AND CONTEXTUAL VARIANTS THROUGH A DIACHRONIC OVERVIEW}

Animal tales are distinctive expressions of the most diverse cultures. ${ }^{4}$ They can be found both in early Eastern cultures and in Greco-Roman antiquity, as well as from the Christian Middle Ages up to the present times in itineraries which show intercultural crossroads between Eastern and Western traditions (Palleiro 1998). Such crossroads can also be found in Argentinean animal tales, which reflect the intertwining between European and vernacular indigenous cultures, in an original blend which is the distinctive feature of national identity.

The main protagonist of Argentinean animal tales is neither the wolf nor the bear or jackal, as in European and Asian ones, but the fox, who is the protagonist of two different cycles. In one of them, the fox assumes the role of a large 
and foolish animal (such as attributed to the wolf in the ATU Index), and in the other one, he plays the part of a smaller, cunning animal threatened by a bigger and mightier tiger. In the cycle of "The Fox and the Tiger" the cunning fox defeats the tiger, representing the victory of the intelligence over the force. In another cycle, the fox is mocked by smaller animals, representing also the victory of cleverness over the force. Other characters of Argentinean animal tales belong to the vernacular fauna. Many of them have local or indigenous names, such as the armadillo (quirquincho or peludo) or the ostrich (suri, in indigenous Quechua language). The role of the fox's nemesis is played not only by the tiger, but also by the armadillo, the lion, or even by different local birds.

In animal tales across cultures, the dominant rhetorical strategy is personification, whereby animals can think and speak in human language. In indigenous cultures, such human embodiment of animals is connected with a worldview in which animals are considered as representations of supernatural forces. In Hispanic tradition folk narrators give human names to the animals; the fox is called John, his wife is Jane, and their children are the Johnnies. This name is also well spread in Latin America and particularly in Argentina, where the fox also receives the vernacular affective diminutive of Juancho.

In the preface to the main folk narrative collection, Cuentos y leyendas populares de la Argentina (Argentinean popular folktales and legends), Berta Elena Vidal de Battini (1980) points out that animal folktales such as the ones of the fox cycle arrived in Argentina with Spanish conquerors in the early sixteenth century, and such cultural heritage is reflected in the way that narrators name the fox Juancho, and other vernacular animals, like the tiger (Simon), and a local bird (Alonsito). ${ }^{5}$

In short, animal tales can be characterized as a folk narrative genre - whose protagonists are animals - that reflects the atmosphere of rural life through the humanization of the vernacular fauna (Kovacci 2000). Such personified animals carry out a series of actions articulated in sequences, which take place in a fictional world. Each version is organized according to narrative patterns or "matrices" stabilized in the diachronic transmission process, which includes scriptural registers and recreations. In this paper, I deal with animal tales collected in Argentinian alternative versions and variants of such narrative patterns whose transformation, connected with local beliefs, expresses the differential identity of vernacular cultures.

To contextualize this approach to the intertwining between animal tales and belief narratives, I will provide a quick diachronic overview of Argentinean folk narrative collections, from 1921 up to the present day. Such collections can be divided into two groups: those including folk narratives of the whole Argentinean territory or "general collections", and those including only regional narrative material. 


\section{ANIMAL TALES IN GENERAL FOLK NARRATIVE COLLECTIONS}

In 1921, the National Council of Education sent a questionnaire to the teachers of all public primary schools of Argentina, resulting in the 1921 Folkloric Survey, which became the first systematic collection of Argentinean Folklore. Schoolteachers had been convoked to work as intermediaries between their pupils and the institutional authorities of the National Council of Education. They were supposed to collect and register folkloric material from young students and their families in written manuscripts, following a series of institutional instructions. Such instructions responded to the nineteenth-century collectionist paradigm of folklore centered on compilation rather than on textual interpretation (Palleiro 2008b). The instructions sent to the teachers by the National Council of Education asked them to compile all the cultural products considered at that time as the most important folk narrative genres: crafts, games, beliefs, customs, rites, and handicrafts, as well as literary forms in verse and prose such as tales or fictions. Folktales were then classified according to thematic parameters, similar to the ones of AaTh Tale Type Index (1928). Both the instructions and the thematic contents of this survey have been listed in a catalogue, published in 1925 under the title of Catálogo de la Colección De Folklore donada por el Consejo Nacional De Educación, by the Institute of Argentinean Literature at the Faculty of Philosophy and Literature at Buenos Aires University.

According to the aforementioned instructions sent to the teachers, animal tales were supposed to be classified as Märchen, along with "marvelous, religious, moral, scary tales, human tales and jokes". ${ }^{6}$ Although these are not appropriate terms of subgenres, this is the way in which they were named in the instructions sent by the National Council of Education. Such instructions asked the teachers, who acted as collectors, to identify versions and variants of an urform; that is to say, to collect different local expressions of a hypothetical original, and the earliest universal folktale pattern then spread in different areas, according to the historic-geographic method of the Finnish school.

The whole survey, kept in a vast manuscript archive now located at the National Institute of Anthropology and Latin American Thought of Buenos Aires, gave place to different textual re-writings.

The 1921 Folkloric Survey acted as a pre-text for textual rewritings, such as the two series of Cuentos folklóricos de la Argentina (Argentinean folktales) by Susana Chertudi (1960, 1964), comprising two volumes, whose first part includes animal tales. The author of this collection is a researcher in the field of folk narrative, with university studies in literature and folklore. The content itself is mainly a textual re-writing of selected narrative material 
from the 1921 Folkloric Survey, with precise classificatory criteria and the addition of versions collected during fieldwork. According to the paradigm of the nineteenth-century Finnish school, this collection contains two "series" or volumes of 100 versions each, classified according to the AaTh Thematic Indexes of Tale Types (1961 [1928]). As previously mentioned, animal tales merely is the first thematic category in this collection, the other categories being marvelous, religious, human, and formula tales. The tales have been classified according to the parameters devised by Antti Aarne and Stith Thompson (AaTh 1961 [1928]), Stith Thompson (1955-1958), and Ralph Boggs (1930), and the collection has been organized with an anthological criterion that privileges the selection of tales over the analytical interpretation. ${ }^{7}$ The first series includes 34 animal tales all featuring the fox as the main character, while the second series includes 30 animal tales, in which the main character is also the fox. Both series include a list of lexical regionalisms, also providing, in footnotes, short explanations regarding phonic, syntactic, and morphological forms of local speech. ${ }^{8}$ In both series of tales, the fox is the focal point of two different cycles within those series. In one cycle he acts as the bigger animal defeated by the little and clever armadillo (quirquincho), while in the other he acts as the smaller and cleverer animal who manages to defeat the bigger and more foolish tiger.

The method of filing up narrative versions of this collection, which contains folk narratives of the whole Argentinean territory, focuses on the geographical diffusion of tale types. Animal tales is the largest category of both series, but it is shorter in length than marvelous tales. Some remarks included in the introduction focus on the structure of the folktale as well as the style and performance of folk narrators, revealing the emergence of new paradigms oriented towards a more communicative dimension of folklore.

Animal tales can also be found in the largest Argentinean folk narrative collection, Cuentos y leyendas populares de la Argentina (Folktales and popular legends of Argentina) by Berta Elena Vidal de Battini. This nine-volume collection, edited in Buenos Aires by Ediciones Culturales Argentinas (1980-1984), with a tenth volume published posthumously in 1995, includes two folk narrative genres: folktales and legends. They are ordered, as the previous volumes, with an anthological criterion that privileges the register over the interpretation and analysis. Battini, who served as both the inspector of primary schools of the National Council of Education and as a research professor of the Hispanic philology and regional dialectology at Buenos Aires University, collected folk narratives of all Argentinean regions and provinces. The method for obtaining and registering folk narrative material was a written questionnaire sent to teachers of primary public schools of all Argentinean provinces, which followed 
the model of the 1921 Folkloric Survey (Consejo Nacional de Educación 1921) with the addition of linguistic and dialectological issues. ${ }^{9}$ The way of classifying folktales was bound to the historic-geographic method of the Finnish school, and to AaTh thematic parameters. According to these parameters, folktales have been divided into: 1) animal tales; 2) magical or marvelous tales; 3) human ${ }^{10}$, moral, and other tales; 4) tales of popular characters like Pedro de Urdemales; 5) accumulative tales; 6) jokes; 7) riddles; 8) novellae ${ }^{11}$; and 9) indigenous narratives. When classifying legends, Vidal de Battini adopted her own criteria. These, as well, are based on thematic parameters, according to which legends have been thematically divided into those referring to 1) places; 2) stones and hills; 3) lakes and rivers; 4) the lost city; 5) hidden treasures; 6) plants; 7) animals; and 8) heaven. Animal tales have been included in the first three volumes of this collection, which contain 841 versions and variants of animal tales, classified according to AaTh parameters. Each group of versions includes a "note" which summarizes the main thematic topics, along with a reference to Aarne-Thompson's tale type number and AaTh thematic description translated into Spanish, as well as a map showing the geographic area across which the tale type spreads.

As is true of many previous collections, the main character of animal tales in this collection is also the fox. In this collection, he is the protagonist of two different cycles: the one of the fox and the armadillo (quirquincho), in which the armadillo outwits the fox, and the one of the fox and the tiger, in which the fox defeats the tiger. Legends deal with mythical characters of vernacular cultures such as the lobizón (werewolf), the uturunco (a sort of tiger with devilish powers), and the mulánima (the "soul-mule", considered as a zoomorphic metamorphosis of the Devil).

The technique of collecting material by means of a "questionnaire" addressed to the "informers", which privileges the semantic content both over the style and over the narrative performance, reveals the impact of the same epistemic paradigm. Vidal de Battini included interesting remarks dealing with the artistic talent of vernacular narrators and references to the cultural environment in her footnotes, showing an opening to a contextualist paradigm. ${ }^{12}$

\section{ANIMAL TALES IN REGIONAL CONTEXTS}

Once the monumental folk narrative corpus of all Argentina was created/collected/ codified in the 1921 Folkloric Survey, contemporary Argentinean collections restricted the area of gathering folk material to regional contexts. Subsequent efforts followed the guidelines of previous collectors such as José Carrizo and 
Guillermo Perkins Hidalgo (1948), whose research has been developed in Corrientes and Catamarca provinces (northeast and northwest Argentina), and Juan Agüero Vera (1965), whose activity as a collector of folk narrative has been focused in the Argentinean province of La Rioja (northwestern Argentina). These new collections reveal the impact of communicative paradigms of folklore focused in contextual variations.

One of the contemporary collections that best exemplifies the tensions between different paradigms of organizing folk narrative material is Cuentos y leyendas de La Pampa (Tales and legends from La Pampa) by Nélida Giovannoni and Maria Inés Poduje (1988). As announced in the title, this text is a regional folk narrative collection which includes tales and legends of La Pampa province. The classification parameters it utilizes for the folktales are similar to the ones adopted by Vidal de Battini, based on Aarne and Thompson's Tale Type Index. Like Vidal de Battini, Giovannoni and Poduje include in their collection folktales and legends, privileging anthological criteria rather than an analytical approach in the same ways.

"Animal tales" is the first taxonomic category of this local anthology, whose texts include vernacular denomination of animals such as peludo (armadillo). The collection includes 59 versions of animal tales, as well as many legends whose protagonists are drawn from local fauna: snakes, birds, mosquitoes, goats, oxen, and owls. Other folktales in this collection are human tales, jokes, tales of the Hispanic trickster Pedro de Urdemales, fool's tales, tall tales, fictional tales or novellae ${ }^{13}$, marvelous, religious, and moral tales. The focus in contextual variations is a distinctive feature of this volume, whose texts include registers of regional speech and references to vernacular fauna, which contextualize universal tale types in the local environment. Local contextualization of universal tale types is one of the main goals of this work. As in Susana Chertudi's (1960, 1964) and Berta Elena Vidal de Battini's (1980-1984) collections, the main character of animal tales is the fox, who acts as a protagonist in two cycles: the first is that of the fox and the armadillo, in which the fox is the antagonist, tricked by the smaller and cleverer armadillo. The second is that of the fox and the tiger, in which the fox acts as the protagonist, who manages to cheat the tiger who is bigger and more foolish than him. Similar to the format of Chertudi's collection, the narratives are based on re-writings of manuscript texts in the 1921 Folkloric Survey responses from the La Pampa region, with the addition of new versions and variants registered in fieldwork by the collectors.

Giovannoni and Poduje (1988) classified animal tales into the following groups: "The fox and the peludo" (16 versions), "The fox and the tiger" (12 versions), "The fox and the partridge" (10 versions), "Other tales of the fox" (20 versions), and "Tales of different animals" (11 versions). In certain animal tales, 
folk types are mixed up with legendary discourse, in an intertwinement of folktales and belief narratives. One notable example of this intertwining can be found in the tale "The fox learns to whistle like the partridge" (AaTh type 58**: "Fox asks thrush to teach him to sing"), narrated by Marcial Fleytoux, and collected by Giovannoni and Poduje in 1986. ${ }^{14}$ This is an etiological narrative which explains that the shape of the fox's mouth seems to be a broken peak because the fox had it sewn shut when trying to whistle like the partridge (Giovannoni \& Poduje 1988: 64). On the other hand, motifs appearing in animal tales can also be found in the legends, as it happens with the legend of the goat. ${ }^{15}$ The goat is said to be a demonic being created by the Devil himself as part of a contest with God, according to the version narrated by Tomás Domínguez in 1986 and collected in Santa Rosa, La Pampa, by Giovannoni and Poduje (Giovannoni \& Poduje 1988: 280-282). It is worth noticing that the versions that show the interweaving with belief narratives are those registered by the collectors during fieldwork, and not those transcribed from the 1921 Folkloric Survey, which have been corrected by the collectors in order to fit with "pure" taxonomic categories, such as animal tales or legends. ${ }^{16}$

\section{TEXTUALIZATION PROCESSES IN MY OWN ARCHIVES OF ARGENTINEAN FOLKTALES}

My own edited archives consist of three anthologies of animal and marvelous tales (Palleiro 1990, 1992, 1998) and three critical editions: one of marvelous tales (Palleiro 2011), one of supernatural tales and belief narratives (Palleiro 2004), and one of animal, marvelous, and human tales, with the addition of an analytical study (Palleiro 2016). All of these collections contain the results of more than twenty years of fieldwork in both rural and urban Argentinean contexts. The anthologies, oriented to a wide range of readers, include more than 50 folktales classified according to the AaTh parameters and Thompson's Indexes of Tale Types and Motifs, updated in the last version according to HansJörg Uther's 2004 revision of Aarne-Thompson's Tale Type Index (ATU 2004). The first two collections of folktales are El escondite mágico y otros cuentos folklóricos riojanos (The magic hiding-place and other Argentinean folktales), edited in 1990, and Los tres pelos del diablo: Cuentos maravillosos de la cultura popular Argentina (The three hairs from the Devil's beard: Marvelous tales from Argentinean popular culture), edited in 1992, mainly comprised of marvelous tales, while the third edition, La fiesta en el cielo: Cuentos populares de animales (The heavenly banquet: Animal folktales), edited in 1998, consists of 20 animal tales, one of which is analyzed in the following section. These animal 
tales have been organized into thematic groups: "The fox and the quirquincho" (armadillo), "The fox and the tiger", "The tiger and the quirquincho", "The fox and other animals", and "Tales of other animals". The main critical edition, whose title is Fue una historia real: Itinerarios de un archivo (It has been a real case: An archive with different itineraries), edited in 2004, contains the results of a post-doctoral research, based on the analytical study of 20 oral versions of a same narrative matrix, "Meeting Death", which shares some thematic features with Thompson E 332.3.3.1., "The vanishing hitchhiker". Although that text does not contain animal tales, I mention it because I deal here with the same concepts I work with when classifying animal tales. The "narrative matrix" is characterized as a set of thematic, structural, and stylistic features which serve as a pre-text to be transformed in different contexts (Palleiro 2004, 2018). An updated rewriting of this work, comprising new versions dealing with belief narratives collected in Argentinean and European contexts was published in 2018, under the title of La dama fantasma: Los laberintos de la memoria en el relato folklórico (The lady ghost: Folktale and the labyrinths of memory).

My largest collection, El cuento folklórico riojano: Una aproximación a la narrativa oral (Folktales from La Rioja, Argentina: An introductory approach to oral narrative), published in 2016, contains an updated rewriting of my doctoral thesis, focused on the study of contextual variations in a collection of Argentinean folk narratives, including animal tales, collected during fieldwork in the Argentinean province of La Rioja. The analysis of animal tales is based on an intertextual comparison with belief narratives regarding the Salamanca local rite, in which men and women suffer a metamorphosis into different animals, as I have explained (Palleiro 2016: 217-264). The climax of this ritual ceremony is the participants making deals with the Devil, who appears in the form of different animals, reflecting a local cosmology in which animals and human beings are closely bound to supernatural forces.

\section{ANIMAL TALES IN INDIGENOUS FOLK NARRATIVE COLLECTIONS}

Argentinean folk narrative collections also comprise oral tales belonging to indigenous cultures, transcribed into both Spanish and vernacular written versions by different scholars. ${ }^{17}$ Else Maria Waag is a pioneering scholar who privileges the analytical dimension and whose work, Tres entidades "weküfu" en la cultura mapuche (Three weküfu entities in Mapuche culture), focuses on the study of the cultural representations of Mapuche evil entities in vernacular narratives (Waag 1982). ${ }^{18}$ 
Martha Blache (1991 [1982]) developed this analytic trend of folklore studies in Estructura del miedo: Narrativas folklóricas guaraníticas (Structure of fear: Guaranytical folk narratives). Such systematic work, based on her doctoral thesis defended at Indiana University in 1977, shifted the perspective of Argentinean folk narrative studies from the one based on anthological criterion and associated with a collectionist paradigm of folklore, towards the one based on analytical interpretations of vernacular folk narrative material. Her analysis is centered on a semiotic approach to a corpus of legends recorded in Spanish from Paraguayan migrants belonging to the Guaranytical culture in Buenos Aires. In such legends, animals are represented as anthropomorphized mythical beings, such as the Yasí-yateré, a sort of South American crocodile considered as a mythical creature. ${ }^{19}$

A relevant register of indigenous Mapuche folktales can be found in Testimonios de los últimos ranqueles (Testimonies of the last Ranqueles), compiled by Ana Fernández Garay (2002). Garay privileges the linguistic dimension of analysis, focusing her interest on the Ranquel variant of the Mapuche language. This work presents a bilingual edition, including a written transcription and translation of oral vernacular registers into Spanish, in varying levels of complexity. The compilation provides not only verbal transcriptions but also audio recordings in an enclosed $\mathrm{CD}$, which were originally collected on the indigenous reservation of Colonia Emilio Mitre in 1983. The reservation is located in the Argentinean province of La Pampa. Folktales, comprised of mostly animal tales, whose main character is usually the fox, are presented as examples of the Ranquel variant of the Mapuche language.

The same trend of research in Mapuche oral expressions has been followed by Marisa Malvestitti, whose doctoral thesis, supervised by Dr. Fernández Garay in Buenos Aires University,$^{20}$ deals with written transcriptions of oral narratives, including animal tales. The thesis was published under the title Kiñe Rakizuam: Textos Mapuche de la Linea Sur (The Mapuche southern variant) in 2005. In another study conducted in collaboration with Antonio Díaz-Fernández (2009), Malvestitti deals with the narrative analysis of Mapuche animal tales such as "Cuento del zorro y la martineta" (Tale of the fox and the martineta). ${ }^{21}$ This vernacular version, which shares some thematic distinctive features with AaTh $58^{* *}$, "The partridge teaches the fox to whistle", presents a flexible sequential order and rhetoric strategies connected with the epew. The epew is a Mapuche folklore genre which can be characterized as a sort of vernacular saga whose protagonists are animals of the local fauna. In the narrative plot, these personified animals deal with conflicts which reflect the struggles of indigenous people in everyday life (Malvestitti \& Diaz Fernandez as cited in Palleiro \& Fischman 2009: 144). This and other texts, accurately registered by Malvestitti and Diaz 
Fernández both in Spanish and in the Mapuche language show an interweaving with aboriginal myths regarding personification of animals (Malvestitti \& Diaz Fernandez as cited in Palleiro \& Fischman 2009: 197-200).

All these collections of animal tales in vernacular languages, whose main goal is to register linguistic variants of indigenous languages facing extinction, reveal the impact of a communicative approach to folklore, based on the ethnography of speaking developed by Dell Hymes (1972).

\section{TRENDS AND TOPICS IN ARGENTINEAN ANIMAL TALES AND FOLK NARRATIVE COLLECTIONS}

This brief diachronic survey across Argentinean collections of animal tales shows some trends in the classification of folk narrative material. The first collections include narratives of the whole country, classified into thematic tale types and organized according to anthological criteria. In these anthological collections, which reflect a strong influence of the nineteenth-century Finnish school, animal tales along with marvelous ones - whose register is based on the re-writing of orality - are the most relevant narrative genres. These texts include footnotes explaining the meaning of vernacular lexical forms, mainly referred to in the local fauna. Philological and historic-geographic approaches dominate in such collections, published in a period during which the main goal of folklorists was registering the texts rather than analyzing contextual performances. ${ }^{22}$

Contemporary collections, instead, reveal the impact of contextualist paradigms, centered in the discursive construction of the narrative message. Such collections also include belief narratives whose protagonists are animals, and some of them even provide different stages of textualizing oral registers. Others include registers of indigenous languages and vernacular narrative genres facing extinction. Nowadays, folk researchers tend to restrict the scope of collecting folk narrative material to specific contexts, with an accurate methodology of registering and analyzing a shorter range of texts both from a linguistic and ethnographic perspective. The previous collectors, instead, used questionnaires to collect and document a wider range of narratives in extended areas of the whole country, with the help of cartographic techniques.

Another trend deals with the broadening of the paradigm of folklore, associated with the oral and anonymous production located in a rural environment, towards the production located also in urban contexts, considered with an analytical approach which highlights the stylistic hallmarks of individual folk narrators. 
This overview of vernacular collections reveals the richness and variety of Argentinean folk narrative collections, whose dynamism can survive political, social, and economic crises, re-signifying the past from the present. Folk narrative is an efficient instrument to achieve this goal, since the semantic content of the message is linked with the expression of social identities.

The concept of narrative matrix (Palleiro 2004, 2018) as a classification instrument adds to the thematic typology of international indexes, structural and stylistic issues which highlight the narrators' capacity to recreate in aesthetic messages the distinctive features of each cultural context, such as that of Argentina. One of these distinctive features of the Argentinean culture is its multiethnic profile, reflected in folk narrative collections. Such multiethnic profiles are connected with the plural convergence of European, Créole, and indigenous groups, along with the diasporic migration of other communities, creating cultural diversity. Animal tales, connected both with the local fauna and with the contextual landscape, act in these collections as metaphoric expressions of vernacular and migration cultures.

\section{FICTION AND BELIEF IN ARGENTINEAN ANIMAL TALES: TEXTS AND INTERTEXTS}

In this section, I deal with an oral version of the narrative matrix "The fox and the raven", whose intertextual connections with ritual discourse show the influence of belief narratives.

The narrator of this version of the narrative, collected in fieldwork done in Villa Mazán (La Rioja, Argentina) in 1987, was Luis Ariel Molina, aged 12. This animal tale, titled "The fox, the female armadillo (quirquincha), the baby armadillos (quirquinchitos) and the raven", was transmitted orally by Molina's mother to her offspring, and shares some thematic features with the type 73, "Blinding the guard", whose thematic description in AaTh is as follows:

The rabbit, imprisoned in a hollow tree, induces his guard to look up at him. He spits tobacco juice into the guard's eyes and blinds the guard, and thus effects his escape.

In ATU, instead, the thematic description of this type is:

A rabbit (fox) who is imprisoned, throws dirt (salt, pepper, tobacco juice) into the eyes of his guard. While the guard is blinded, the rabbit escapes. ${ }^{23}$ 
The ATU description offers a generalization which fits better to different variants of this tale than the one of AaTh. This means that, when elaborating an Argentinean folk narrative catalogue, it is worth choosing the thematic universal description which is more likely to fit better with the contextual variants. However, it is worth pointing out that the choice should be done for each tale type separately, and not as a general rule, since there are Argentinean folktales which fit better with the ATU description, and others that fit better with AaTh.

All the animals alluded to in this version belong to the Argentinean fauna and are mentioned with their local names, as it happens both with the personified female armadillo (quirquincha) and with the raven or jote, who replace the rabbit and the tiger as the guardians in the universal tale type. Such changing details show the connection with the Argentinean local context of a rural community, in which the topic of the triumph of the small animal over the big one acquires special relevance. In fact, in the community where the struggle for survival in a difficult environment as well as the struggle of the humble people against the oppressors is a daily concern, the tales of the fox and the armadillo were the most frequent ones in the repertoire of rural folk narrators. ${ }^{24}$

In Molina's version, the axis of the narrative conflict is that of deceit, thanks to which the female armadillo (quirquincha) manages to cheat both the fox and the raven, who want to eat her and her sons, as it can be seen in the following text.

Once, there was a female armadillo (quirquincha). And she was there, sitting with her three little sons near the cave, facing the sun.

And then the fox came, and he said: 'Armadillo (quirquincha), I want to eat you!'

'Well, well! But let me first sing three little songs!'

'Alas, my fortune! Armadillo (quirquincho) in cave!' she sang for the first time. And while she was singing, she was also pushing the first baby armadillo (quirquinchito) into the cave.

And the fox began laughing, as he saw the armadillo singing and pushing.

In the meantime, the armadillo was hiding the baby armadillos inside a narrow, deep and winding cave. She was at the same time singing and pushing the babies into the cave. And she did this for three times, and then, she herself entered the cave, she went running deep inside.

And then, a raven came over; a raven who was overflying just there.

That the raven is always flying around, in a search of a prey to eat. It is said that the raven had been a human being, and that the devil 
transformed him into a carrion bird, who eats the flesh of dead animals. ${ }^{25}$ And it is said that this happened because he refused to worship the Devil in the Salamanca rite. That the raven has been a good dancer who used to dance at the Salamanca, and when he was supposed to offer his soul to the Devil, he didn't do so, he refused. And this is why the raven is always looking for the flesh of dead animals.

And that the fox knew all this, so he said: 'Come on, come on, brother! Come on, here! I have a job to offer you: you must just stay here, at the entrance of this cave, keeping your eyes widely open!' he said. You must pay attention, because you can't let the baby armadillos escape from this cave! 'I'll bring a shovel to push them out when I return, so we can catch them and eat them,' the fox said. 'So, with the shovel I will bring, I am going to push them out, and then both of us are going to eat them! But they must remain in the cave until my arrival.'

And that the fox went to fetch a shovel, and the raven remained there, at the entrance of the cave, with his eyes widely open, watching and watching.

And then, well, he, the raven, remained there, with his eyes widely open, like this. [The narrator makes the gesture of opening his eyes, and then he suddenly closes them while he makes the movement of throwing something into his eyes with the right hand.]

And then, suddenly, the armadillo (quirquincha) grabbed a handful of dust and threw it into the raven's eyes. And thus, the raven closed his eyes. And he began to wallow, and he fell down, he rolled down. And then, since he had been blinded, he couldn't see where he was going, so he entered another large cave.

And then, the fox came back with a shovel, and: 'What is this? What's going on here?' he asked, when he saw the raven inside the other cave.

'The armadillo (quirquincha) hurt my eyes, she threw me a handful of dust into my eyes!' said the raven.

And then the raven began mourning, he began crying. 'And now I am going to eat you!' the fox threatened the raven.

And he ate him. Just like that, the fox ate the raven.

And, in the meantime, the armadillo (quirquincha) managed to escape with her babies.

And so, the poor raven was fucked over, and the fox ate him, instead of eating the armadillo (quirquincha) and her babies. It was just like that.

That was what happened to the armadillo (quirquincha) and her babies: they managed to escape from the fox. (Palleiro 2016 (CD)) 
In this narrative, the conflict, dealing with the deceit of the big animal, takes place in a macro-sequence whose climax is the threat of the fox to the female armadillo. At first, the armadillo manages to outwit the fox by hiding her children in a cave in the episode which precedes the one of "The blinded guard". Such deceit is the main thematic topic of the matrix "The fox, the raven, and the armadillo", whose rhetorical axis is the personification of animals along with the antithesis between strength and cunningness. The structural axis of this narrative is based on the flexible combination of different episodic units, and such flexibility results in the addition of a preceding sequence before the climax of the deception of the fox. The armadillo makes the fox laugh while she delivers her sons inside the cave and in this way she outwits the fox, hiding her children. By doing this, she manages to escape with her offspring, blinding the guardian, represented by the raven. The narrative matrix includes the combination of these structural, rhetoric, and thematic features, which include the universal topic of the blinded guard, recreated in the local Argentinean context.

\section{THE INTERTEXTUAL CONNECTIONS: COSMOGONIC TALES AND RITUAL SPEECH}

The connection of this folktale with ritual speech becomes clear in an explanatory clause, included in the sequence in which the fox threatens the female armadillo. Such a connection can be seen in the intertextual comparison with other belief narratives collected from other narrators of the same community, in a similar period. One of these is the narrative produced by Marino Cordoba, "The Salamanca and other social beliefs", which I recorded in an oral interview held in La Rioja in 1987 (Palleiro 2016). In this interview, Cordoba, a local ceramist and creator of a series of pottery statuettes related to the Salamanca, explained the sequential development of this rite. ${ }^{26}$

According to Cordoba, the Salamanca is a ritual ceremony in which "a man or a woman sell their soul to the Devil", whose climax is the moment in which this "deal with the Devil" is achieved (Cordoba as cited in Palleiro 2016: 54-58). In such a ceremony, those that refuse to make such a deal are punished and transformed into ugly animals. After having narrated this ritual climax, Cordoba alluded to the raven as one of the "punished" participants, whose ugly embodiment is a consequence of a penalty due to this refusal: 


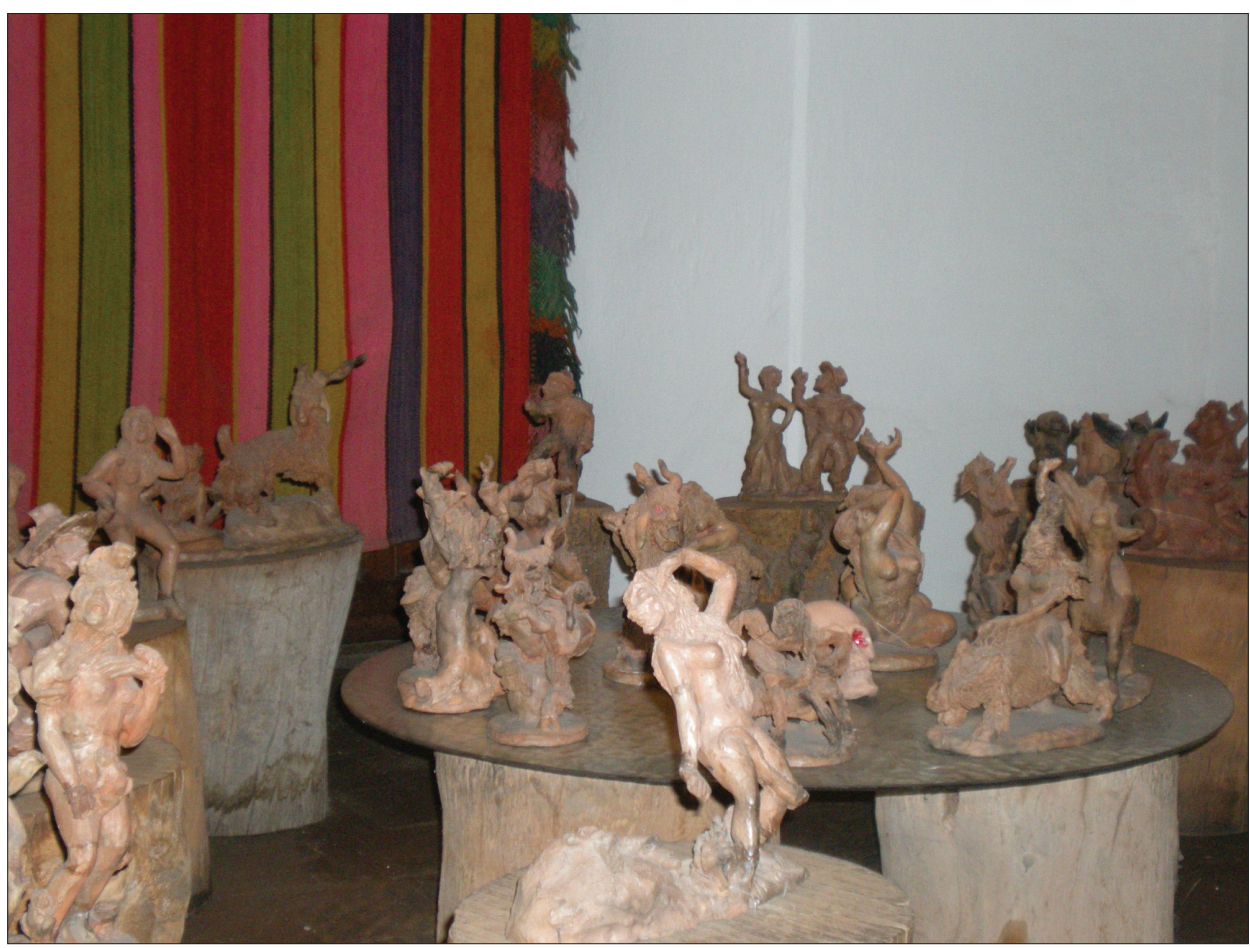

Figure 1. The Salamanca by Marino Cordoba in La Rioja Museo Folklorico. Photograph by Analia Canale 2013.

And there are also the "punished" ones: the caranchi, the vulture, the raven, the jote, who has also been a handsome dancer. And he became an ugly dirty animal, a carrion eater, who eats the flesh of dead animals, because he refused to sign a contract with the devil.

[Cordoba shows the pottery statuette of a stylized raven, whose form resembles the one of a dancer in a human form, with wings instead of arms, and an ugly beak.] (Cordoba as cited in Palleiro 2016: 58)

There is an intertextual connection between the episode of Molina's tale dealing with the ugliness of the raven as the guardian of a cave, and the sequence of the Salamanca rite dealing with the jote. In fact, the Salamanca rite is often performed in a cave, similar to the one where the female armadillo (quirquincha) hides her babies in Molina's narrative. In a metaphorical procedure, Cordoba identifies the raven with a "punished" dancer, whose penalty has been caused by his denial to accomplish the Salamanca, which is the name of both the cave 
and the ceremony. In a similar way, the young narrator Molina connects this narrative sequence with the Salamanca rite as an explanatory clause in which he alludes to the zoomorphic transformation of the raven. In Cordoba's discourse such a transformation is associated with the devilish ritual whose distinctive feature is the contrast between a beautiful appearance and a monstrous essence.

Additionally, Molina's clause links the origin of the raven as a carrion eater with a ritual punishment, in an etiological discourse ("The raven had been a human being, and the devil transformed him into a carrion eater bird... because he had refused to worship the Devil in the Salamanca rite" (Palleiro 2016: 254)). According to the narrative plot referred to by Molina, the raven, presented in the aforementioned clause as a zoomorphic metamorphosis of a human being, is the blinded guardian who acts as a helper of the fox, outwitted by the female armadillo (quirquincha). In this way, the defeat of the raven acquires the meaning of a ritual punishment, connected with social beliefs of the local context.

These contextual transformations of folk narrative matrices can be identified not only in the thematic plot, but also in the sequential organization, as well as in the rhetorical construction of the narrative discourse. As it is, in the local context, the personification of animals acquires not only the value of a rhetoric strategy but also the meaning of a social belief, dealing with zoomorphic metamorphosis of human beings into animals. Such zoomorphic transformations, caused by devilish forces, are connected with the antithesis between reality and appearance. In this way, this antithesis becomes both the axis of the Salamanca rite and the dominant rhetoric strategy of this series of animal tales, in which the apparently weaker animal manages to defeat the stronger one.

In Molina's narrative, the addition of an explanatory clause highlights the relevance of social beliefs in transforming folk matrices. In fact, the reference to the ritual punishment of the jote - a vernacular name of the raven - resemantizes the message, showing an intertextual connection of the folktale with belief narratives. In this way, both Cordoba's and Molina's discourses deal with "rhetoric of believing" (Palleiro 2008a) oriented to convince the audience of the credibility of the narrative discourse.

As affirmed in the introductory part of this article, belief narratives deal both with the ontological dimension of truth and with a social consensus. Such a connection is mentioned by Cordoba himself in a metanarrative clause, when referring to the Salamanca rite. In this clause, he stresses the relationship between folktales and belief discourse, considering the Salamanca as a "true rite" which serves as inspiration for fictional tales: "All that happens in the Salamanca is true, since it is a rite which must be accomplished. But from this rite people find inspiration to tell histories and fictional tales" (Cordoba as cited in Palleiro 2016: 58). 
As I pointed out in my previous work, in which I dealt with this interview (Palleiro 2016: 217-264, especially 251-253), such affirmation shows that fictional tales and histories can be considered as alternative itineraries of the same narrative matrix, the tale being closer to the fictional domain, and the rite closer to social beliefs. Nevertheless, all these parameters prove to be flexible categories, which reveal a mixture of different narrative genres. This mixture should be shown both in the textualization of folk narrative texts and in their classification in folk narrative catalogues.

\section{FINAL CONSIDERATIONS}

The diachronic overview of Argentinean folk narrative collections reveals that belief narratives, reduced in the first collections to minor categories such as superstitions, gain space in contemporary ones, illustrating how an a priori taxonomic criterion such as the collectionist paradigm of the nineteenth-century Finnish school has been gradually replaced by a contextualist and performancecentered one. In fact, belief narratives are closely bound to local contexts, whose cultural distinctive features are recreated in each textual message.

Besides, both the textual analysis and the intertextual comparison of Argentinean animal tales show the interweaving between folktales and belief narratives, in a mixture of legendary, ritual, mythical, and fictional discourse. In the texture of animal tales analyzed in this article, there is in fact a vanishing gap between fiction and reality, rooted in social beliefs, and such a vanishing gap should be reflected in the classification of Argentinean animal tales, along with the blend of different folklore genres. The inclusion of textual examples of this blend would be the best way of underlining such generic mixture in a catalogue of Argentinean folk narrative. In such a vernacular catalogue, the order of the folktales could remain the same as in the ATU international index, whose numbers correspond to ATU 1-299, replacing types with matrices. The concept of folk matrix proves to be, in this sense, a flexible taxonomic issue, which allows for the connection of alternative itineraries of the same narrative patterns, such as the ones analyzed in this article. The alternative itineraries of each narrative matrix, textualized into numerous versions, are similar to those of a virtual hypertext, characterized as a flexible combination of semantic units whose changing details can also be considered as variants.

An updated catalogue of Argentinean tales should reflect these distinctive features of vernacular folk narrative in a flexible dialogue with international classification criteria, enriching both the world map with local variations and the 
local map with a taxonomic reference to global cultures. Animal tales included in such a catalogue, as metaphoric symbols of local worldviews, can reflect the differential way of narrating social identities, in an intertwining between fictional and belief narratives.

\section{ACKNOWLEDGEMENTS}

Gentle acknowledgment is due to Monika Kropej Telban not only for having provided updated bibliography regarding animal tales but also for having shared her experience regarding the classification of Slovenian animal tales; to Barbara Ivančič Kutin for having shared information and documentation regarding Slovenian folk narrative collections; to Mirjam Mencej for the clever reading, comments and bibliographical information regarding folklore genres, and to the reviewers, for their bibliographical information regarding Märchen types and international folk narrative collections; to Jessica Gardner for the careful and clever revision of the whole text in English.

\section{NOTES}

1 It is worth noticing that Becker (2010: 542), in his updated overview of animal tales and collections, mentions literary recreations of animal tales, such as Joanne K. Rowling's saga of Harry Potter, which can be considered as an example of fantastic literature.

2 Such parameters regarding theme, structure, and style are inspired by the ones used by Bajtín (1982) when defining discursive genres.

3 For a specific study of a hypertextual approach to folk narrative discourse, see Palleiro (2004, 2018).

${ }^{4}$ For an accurate definition of animal tales, see Bies (2010). For an approach to animal tales as a folklore genre see Uther (2010). For an updated diachronic overview of types, topics, collections, and literary recreations of animal tales, see Becker (2010). Perhaps due to the lack of catalogues, none of these authors include in their bibliography references to Argentinean collections whose distinctive features deserve to be taken into account in an overview of animal tales. This is the reason that encouraged me to face the task of providing a catalogue of Argentinean animal tales classified according to international standards.

5 Alonsito is the given name of a local bird, the hornero or oven bird, so called because his nest has the size of an oven. 
6 The instructions mentioned also other folklore subgenres, such as legends, memories, traditions, myths, anecdotes, and "uncanny cases". The way the different subgenres are named corresponds to the denomination used ad passim in the catalog of the 1921 Folkloric Survey, whose title is Catálogo de la Colección De Folklore donada por el Consejo Nacional De Educación (1925).

7 In this collection, narrators are considered as informers and identified with name, surname, age, place of birth, and place of residence. Besides, in the same way as in the 1921 Folkloric Survey, "realistic tales" are also named as "human tales".

8 When analyzing textualization methods of oral versions, it is worth noticing the absence of tape recorders and other sound-reproducing devices at the time in which these folktales were collected and transcribed.

9 The model of such a linguistic questionnaire has been recently published by the research team of the Institute of Philology and Linguistic Research of San Juan University, Argentina, led by Aida González (2010). This Institute owns the Vidal de Battini Archive (FONVIBA) containing the written manuscripts with the results of the survey in which, curiously, all the manuscripts regarding folktales have been carefully torn off, as I could see in my last visit to this archive in November 2018.

10 "Human tales" is the parameter used by Vidal de Battini in this collection, instead of "realistic tales".

11 "Novella" is the parameter used by Vidal de Battini to classify realistic tales.

${ }^{12}$ For a complete synopsis of Vidal de Battini's profile as a folk narrative researcher, see Palleiro (2014).

${ }^{13}$ In the same way as Vidal de Battini, the authors use the term novella to refer to "realistic tales".

${ }^{14}$ The thematic description of this tale type, according to AaTh, is: "Thrush consents if fox will bring needle and thread. Thrush sews up snout of fox and he sings. While hunting quail he shouts too loud and breaks thread". Although the AaTh index was updated by Hans-Jörg Uther in 2004, and the reference used in folk narrative studies corresponds to ATU, in this paper I follow the reference used by the authors in 1988. Besides, the thematic content of Argentinean versions belonging to edited collections is closer to the AaTh description, perhaps because many collectors chose to include in their anthologies the versions that were similar to the universal types as descripted in the index.

${ }^{15}$ In this version, the goat, belonging to the local fauna, is called with the vernacular name chiva, instead of cabra, as the goat is named in standard Spanish.

${ }^{16}$ For the sake of shortness, I omit here the comment of other regional collections, such as Cuentos de las tres abuelas (Stories of three grandmothers) by Silvia García and Diana Rolandi (2000), in which the narrators are three grandmothers from Antofagasta de la Sierra of the Argentinean Catamarca province. This collection consists of different oral narratives including animal tales whose scriptural transcription shows three different phases of textualizing folk narrative texts, as analyzed in Palleiro 2011. 
The first part focuses on different oral narratives of the grandmothers, in a written textualization which includes animal tales of the vernacular fauna, ordered according to the cycles of the seasons (spring, summer, autumn, winter). The first part is then rewritten as a second part in the frame of folktales, presented as stories for children. Such stories have been illustrated by children themselves, and classified by García and Rolandi into thematic categories, similar to those of the Aarne-Thompson's Tale Type Index, as marvellous tales, animal tales - in which the fox is the main protagonist, along with other animals of the local fauna - and human tales, with the addition of some contextual categories like narratives regarding the Pacha - a female goddess representing Mother Earth - in Quechua culture.

${ }^{17}$ For the sake of shortness, I also omit in this overview the narratives collected by "travelers" and early miscellaneous collectors such as Lehmann Nitzche, and also others, as the collection by Berta Koessler Ilg (2006 [1962]), analyzed in Palleiro (2011).

${ }^{18}$ From the pioneers of collecting indigenous versions in vernacular languages, it is worth mentioning the linguistic research of Eusebia Martín (1969: 75), who collected a version of ATU 33 in the Aymara language, "The fox plays dead and is thrown out of the pit and escapes", published in a linguistic study of phonology and morphology of the Aymara vernacular language, with a systematic criterion of transcription (Martín 1969: 75). In this version, the protagonists are not the fox and the tiger but the fox and the donkey, who plays dead and, in this way, manages to trick the fox.

${ }^{19}$ For the sake of shortness, I also omit the comment of other collections of indigenous narratives, such as César Fernández's anthology Cuentan los mapuches (The Mapuches tell) published in 1995. In this collection, for which vernacular folktales have been translated into Spanish, the author has included a preliminary study of Mapuche poetics, organized in different folklore genres. Such an anthology offers a miscellaneous mixture of folk narratives, classified into mythical tales, conversations between paysans, legends - including mainly animal legends - prayers, and folktales. The relevance of animal tales led the author to include them into three different categories: one regarding animals, the second regarding only the fox, and the last one in which the fox is identified with a human name such as John.

${ }^{20}$ It is worth remembering that Dr. Fernández Garay is the author of one of the most relevant contemporary collections of folktales in the Mapuche language, as explained in the first part of this article.

${ }^{21}$ In this version collected by Malvestitti (2005), the partridge of the universal type is replaced by the martineta, a local bird. The title of this version by Maria Cona, narrated in the Mapuche language, is "Epew ng[ur[u kay war".

${ }^{22}$ It is worth noticing that the same trend has been documented in this period in other parts of the world, such as Estonia, as Ülo Valk points out when affirming that "philological approaches have dominated in Estonian folkloristics; it has become a scholarly tradition to work with the texts in archives. Estonian folkloristics has been influenced by the historic-geographic method, known also as the Finnish school" (Valk 2001: 207).

${ }^{23}$ Although there is a Spanish translation of the ATU index, made by F. Peñalosa, it has not been used by Argentinean collectors, so I decided to use the English version to discuss the classification system of Argentinean folktales. See also note 18. 
${ }^{24}$ For further considerations regarding the main topics chosen in the repertoire of animal tales of Argentinean folk narrators of La Rioja, see Palleiro 1998.

${ }^{25}$ The anaphoric use of "well", "that", "and that", "and then", as well as pleonastic repetitions of the narrative discourse, are distinctive features of vernacular oral speech. In fact, this textualization tries to reflect such distinctive features of Argentinean Spanish of La Rioja province in an English translation.

26 The rite consists of a sequential repetition of actions, with a performative intention of achieving effects on the context (Rappaport 1992; Palleiro 2008). One of the performative effects of the Salamanca rite is a punitive action, oriented towards the dancer who has not fulfilled the act of offering his soul to the devil, which is the axis of this ritual ceremony (Palleiro 2011).

\section{REFERENCES}

AaTh 1961 [1928] = Aarne, Antti \& Thompson, Stith. The Types of the Folktale: A Classification and Bibliography. Antti Aarne's Verzeichnis der Märchentypen (FFC No. 3) translated and enlarged. Second revision. Folklore Fellows Communications 184. Helsinki: Academia Scientiarum Fennica. Available at https://www.scribd.com/document/397895185/Folklore-Fellows-Communications184-Antti-Aarne-Stith-Thompson-The-Types-of-the-Folktale-A-Classificationand-Bibliography-Academia-Scientiarum-F, last accessed on 12 September 2019.

Abrahams, Roger D. 1971. Personal Power and Social Restraint in the Definition of Folklore. The Journal of American Folklore, Vol. 84, No. 331, pp. 16-30. http:// dx.doi.org/10.2307/539730.

Agüero Vera, Juan Zakarías1965. Cuentos populares de La Rioja. La Rioja: Imprenta del Estado y Boletín Oficial.

Assman, Jan 1997 [1992]. La memoria culturale: Scrittura, ricordo e identità politica nelle grandi civiltà antiche. Torino: Einaudi.

Astapova, Anastasiya 2015. Negotiating Belarusianness: Political Folklore Betwixt and Between. Tartu: University of Tartu Press. Available at https://dspace.ut.ee/ handle/10062/49509, last accessed on 19 September 2019.

ATU 2004 = Uther, Hans-Jörg. The Types of International Folktales: A Classification and Bibliography, Based on the System of Antti Aarne and Stith Thompson. Folklore Fellows Communications 284-286. Helsinki: Academia Scientiarum Fennica.

Bajtín, Mijaíl [Bakhtine, Mikhail] 1982. Estética de la creación verbal. México: Siglo Veintiuno. Available at https://www.academia.edu/32690288/, last accessed on 19 September 2019.

Barthes, Roland et al. 1970. Lo verosímil. Buenos Aires: Tiempo Contemporáneo. Available at https://monoskop.org/images/4/47/Barthes_Roland_Todorov_ Tzvetan_Lo_veros\%C3\%ADmil_1970.pdf, last accessed on 13 September 2019.

Barthes, Roland 1971. El discurso de la historia. Buenos Aires: Centro Editor de América Latina. 
Becker, Siegfried 2010. Tier, Tiere. In: Enzyklopädie des Märchens. Band 13. Berlin \& New York: De Gruyter, pp. 540-550.

Bies, Werner 2010. Tiermärchen. In: Enzyklopädie des Märchens, Band 13. Berlin \& New York: De Gruyter, pp. 624-627.

Blache, Martha 1991 [1982]. Estructura del miedo: Narrativas folklóricas guaraníticas. Buenos Aires: Plus Ultra.

Blécourt, Willem de 2012. The Problem of Belief Narratives: A Very Short Introduction. Newsletter of the International Society for Folk Narrative Research, No. 6, pp. 36-37. Available at http://www.isfnr.org/files/isfnr_newsletter_2012.pdf, last accessed on 19 September 2019.

Boggs, Ralph S. 1930. Index of Spanish Folktales. FF Communications 90. Helsinki: Academia Scientiarum Fennica.

Bruner, Jerome 2003. La fábrica de historias: Derecho, literatura, vida. Buenos Aires: Fondo de Cultura Económica. Available at https://www.academia.edu/31862782/, last accessed on 19 September 2019.

Butcher, Samuel H. 1902. The Poetics of Aristotle with Critical Notes and a Translation. London: Macmillan and Co.

Carrizo, Jesús \& Perkins Hidalgo, Guillermo 1948. Cuentos de la Tradición Oral Argentina. Revista del Instituto Nacional de la Tradición, Vol. I, No. 1, pp. 51-101.

Catálogo de la Colección De Folklore donada por el Consejo Nacional De Educación 1925. Buenos Aires: Instituto de Literatura Argentina, Facultad de Filosofía y Letras, Universidad de Buenos Aires.

Chertudi, Susana 1960. Cuentos folklóricos de la Argentina: Primera Serie. Buenos Aires: Ediciones del Instituto Nacional de Filología y Folklore.

Chertudi, Susana 1964. Cuentos folklóricos de la Argentina: Segunda Serie. Buenos Aires: Ediciones del Instituto Nacional de Antropología.

Consejo Nacional de Educación 1921 = Colección de Folklore: Encuesta folklórica del Consejo Nacional de Educación a los maestros de las escuelas Ley Láinez. Buenos Aires: Hemeroteca del Instituto Nacional de Antropología y Pensamiento Latinoamericano.

Dégh, Linda 2001. Legend and Belief: Dialectics of Folklore Genre. Bloomington \& Indianapolis: Indiana University Press.

Derrida, Jacques 1997. Mal de archivo Una impresión freudiana. Madrid: Trotta.

Díaz-Fernández, Antonio \& Malvestitti, Marisa 2009. Entre tradición y renarración. La manifestación narrativa mapuche mediante el epew. In: María Inés Palleiro \& Fernando Fischman (eds.) Dime cómo cuentas: Narradores folklóricos y narradores urbanos profesionales. Buenos Aires: Miño y Dávila, pp. 143-155, 197-205. Available at https://www.academia.edu/23385148/, last accessed on 19 September 2019.

Ducrot, Oswald \& Todorov, Tzvetan 1983. Diccionario enciclopédico de las ciencias del lenguaje. Madrid: Siglo Veintiuno.

Fernández Garay, Ana 2002. Testimonios de los últimos ranqueles. Buenos Aires: Instituto de Lingüística, Facultad de Filosofía y Letras, Universidad de Buenos Aires. 
Fernández, César 1995. Cuentan los mapuches. Buenos Aires: Nuevo Siglo.

García, Silvia P. \& Rolandi, Diana S. 2000. Cuentos de las tres abuelas. Buenos Aires: Unesco.

González, Aída et al. 2010. Fondo Berta Vidal de Battini FONVIBA: estudios lingúísticoetnográficos en el contexto del bicentenario de la Revolución de Mayo. San Juan: Universidad Nacional de San Juan.

Giovannoni, Nélida \& Poduje, María 1988. Cuentos y Leyendas de La Pampa. Santa Rosa de La Pampa: Dirección General de Cultura de la Provincia de La Pampa.

Greimas, Algirdas \& Courtés, Joseph 1982. Semiótica: Diccionario razonado de la teoría del lenguaje. Madrid: Gredos.

Hufford, David J. 1995. Beings Without Bodies: An Experience-Centered Theory of the Belief in Spirits. In: Barbara Walker (ed.) Out of Ordinary: Folklore and the Supernatural. Utah: Utah State University Press, pp. 11-45.

Hymes, Dell 1972. The Contribution of Folklore to Sociolinguistic Research. In: Americo Paredes \& Richard Bauman (eds.) Toward New Perspectives in Folklore. Austin \& London: The University of Texas Press, pp. 42-50.

Koessler-Ilg, Berta 2006 [1962]. Cuenta el pueblo mapuche. Santiago de Chile: Mare Nostrum.

Kovacci, Ofelia 2000. Berta Elena Vidal de Battini y sus estudios de la lengua y el Folklore. Boletín de la Academia Argentina de Letras, Vol. 65, No. 257-258, pp. 327-344.

Kropej Telban, Monika 2015. Tipni indeks slovenskih ljudskih pravljic: Živalske pravljice in basni. [The Type Index of Slovenian Folktales: Animal Tales and Fables.] Ljubljana: Inštitut za slovensko narodopisje ZRC-SAZU.

Lakoff, George \& Johnson, Mark 1987. Metáforas de la vida cotidiana. Madrid: Cátedra. Malvestitti, Marisa (comp.) 2005. Kiñe Rakizuam: Textos Mapuche de la Linea Sur. Buenos Aires: Facultad de Filosofía y Letras, Universidad de Buenos Aires.

Martín, Eusebia Herminia 1969. Bosquejo de estructura de la lengua aymara: Fonología. Morfología. Buenos Aires: Instituto de Filología y Literaturas Hispánicas Dr. Amado Alonso, Facultad de Filosofía y Letras, Universidad de Buenos Aires.

Mukařovský, Jan 1977. Detail as the Basic Semantic Unit in Folk Art. In: J. Burbank \& P. Steiner (transl. \& eds.) The Word and Verbal Art: Selected Essays by Jan Mukařovský. New Haven: Yale University Press, pp. 180-204.

Nelson, Theodor Holm 1992. Literary Machines 90.1. Padova: Muzzio Editore.

Noia Campos, Camiño 2010. Catálogo tipológico do conto galego de tradición oral: Clasificación, antología y bibliografía. Vigo: Servicio de Publicaciones de la Universidad de Vigo.

Palleiro, María Inés 1990. "El escondite mágico" y otros cuentos folklóricos riojanos. Buenos Aires: Ediciones del Dock.

Palleiro, María Inés 1992. Los tres pelos del diablo: Cuentos maravillosos de la cultura popular argentina. Buenos Aires: Ediciones del Sol. Available at https://www. academia.edu/23266270/, last accessed on 20 September 2019.

Palleiro, María Inés 1998. La fiesta en el cielo: Cuentos populares de animales. Buenos Aires: Ediciones del Sol. Available at https://www.academia.edu/23266015/, last accessed on 20 September 2019. 
Palleiro, María Inés 2004. Fue una historia real: Itinerarios de un archivo. Buenos Aires: Facultad de Filosofía y Letras, Universidad de Buenos-Aires.

Palleiro, María Inés 2008a. Yo creo, vos sabés? Retóricas del creer en los discursos sociales. Buenos Aires: Facultad de Filosofía y Letras, Universidad de Buenos Aires. Available at https://www.academia.edu/17412270/, last accessed on 20 September 2019.

Palleiro, María Inés 2008b. Archives of Argentinean Folk Narrative: Trends, Topics and History of Argentinean Folkloristics. International Society of Folk Narrative Research Newsletter, Vol. 20, pp. 20-28.

Palleiro, María Inés (ed.) 2011. Jornada "Archivos de Narrativa Tradicional Argentina” (ANATRA). Buenos Aires: Instituto de Filología y Literaturas Hispánicas Dr. Amado Alonso, Universidad de Buenos Aires. (CD enclosed).

Palleiro, María Inés 2014. Vidal de Battini, Berta Elena. In: Enzyklopädie des Märchens, Band 14. Berlin \& New York: De Gruyter, pp. 1843-1846.

Palleiro, María Inés 2016. El cuento folklórico riojano: Una aproximación a la narrativa oral. Buenos Aires: La Bicicleta.

Palleiro, María Inés 2018. La dama fantasma: Los laberintos de la memoria en el relato folklórico. Buenos Aires: La Bicicleta.

Palleiro, María Inés \& Fischman, Fernando 2009. Dime cómo cuentas: Narradores folklóricos y narradores urbanos profesionales. Buenos Aires: Miño y Dávila.

Rappaport, Roy (ed.) 1992. Ritual. In: Richard Bauman (ed.) Folklore, Cultural Performance and Popular Entertainments. A Communications-Centered Handbook. New York \& Oxford: Oxford University Press, pp. 249-260.

Siikala, Anna-Leena 2002. Mythic Images and Shamanism: A Perspective on Kalevala Poetry. Folklore Fellows Communications 280. Helsinki: Suomalainen Tiedeakatemia.

Tangherlini, Timothy R. 1990. "It Happened Not Too Far from Here...”: A Survey of Legend Theory and Characterization. Western Folklore, Vol. 49, No. 4, pp. 371390. http://dx.doi.org/10.2307/1499751.

Thompson, Stith 1955-1958. Motif-Index of Folk-Literature. Copenhagen \& Bloomington: Indiana University Press.

Todorov, Tzvetan 1981 [1980]. Introducción a la literatura fantástica. México DF: Premia. Available at http://iesliteratura.ftp.catedu.es/lectura/cuarto_atras/imagenes/ Todorov.pdf, last accessed on 20 September 2019.

Uther, Hans-Jörg 2010. Tierschwank. In: Enzyklopädie des Märchens, Band 13. Berlin \& New York: De Gruyter, pp. 637-642.

Vidal de Battini, Berta Elena 1980-1984. Cuentos y leyendas populares de la Argentina I-IX. Buenos Aires: Ediciones Culturales Argentinas.

Vidal de Battini, Berta Elena 1995. Cuentos y leyendas populares de la Argentina X. Buenos Aires: Secretaria de Cultura, Ministerio de Cultura y Educación. Available at https://concienciaambientalorg.files.wordpress.com/2019/01/cuentos-y-leyendaspopulares-de-la-argentina-tomo-10-0.pdf, last accessed on 17 September 2019.

Waag, Else Maria 1982. Tres entidades “wekufü” en la cultura mapuche. Buenos Aires: EUDEBA. 
White, Hayden 1973. Metahistory: The Historical Imagination in Nineteenth-Century Europe. Baltimore \& London: The Johns Hopkins University Press.

Valk, Ülo 2001. The Black Gentleman: Manifestations of the Devil in Estonian Folk Religion. Folklore Fellows Communications 276. Helsinki: Suomalainen Tiedeakatemia.

Maria Ines Palleiro, $\mathrm{PhD}$, is senior research fellow at the National Scientific and Technical Research Council, Argentina, and full professor at the National University of Arts / Buenos Aires University. Her fields of research include folk narrative, belief narratives, and social semiotics. marinespalleiro@gmail.com 